\title{
POLICY AND PROGRAM INCENTIVES AND THE ADOPTION OF AGROFORESTRY IN MISSOURI
}

\author{
Ebitari O. Fregene \\ Dr. Corinne Valdivia
}

\begin{abstract}
More landowners in the USA are concerned about management of their lands and natural resources in light of the negative effects of many agricultural practices on the environment. Land conservation program incentives, which include agroforestry, were designed by government agencies to ameliorate the problem. The study identifies the characteristics of adoption of agroforestry practices, and participation in state and federal government incentive programs that include trees and those that do not. The data from this study is drawn from a 2006 survey of 360 landowners conducted in four counties in two regions of Missouri, USA, selected because of their proximity to agroforestry research centers, their rural or urban character, and a land holding greater than ten acres. Logistic regression is used to evaluate the effect of the independent variables on adoption. The results show that age, advice from landowners/farm operators, conservation magazines they subscribe to, familiarity with the practices and personal knowledge of the practices are significant determinants of adoption. Participation in programs was not significant. Lessons are drawn on how sources of information can increase knowledge and encourage stewardship practices that incorporate trees in the context of very diverse groups of landowners.
\end{abstract}

